\title{
Uso de una mezcla Radiopaca y Bacteriostática para Radiodiagnóstico en la Esterilidad Femenina
}

\author{
Estudios Clinicos con Controles Experimentales (conejos) \\ y Bacteriológicos.
}

\author{
Doctor Antonio Karczmar \\ Miembro del Cuerpo Medico del "The American British Cowdray Hospital". \\ de México, D. F.
}

1.-Se da a conocer el empleo de una mezcla flúida L. E. (Lipiodol F (40\%)-Eter al 5:1), para histerografías e histerosalpingografías.

2.-Con las ventajas de gue:

a) Se requieren pequeñas cantidades de sustancia yodada de contraste debido a su mezcla con éter.

b) Casi indolora.

c) Se puede recuperar la sustancia de contraste de la matriz después de cada radiografía, debido a la expansión del éter contenido en la mezcla y utilizar inmediatamente después en las siguientes radiografías, en la misma enferma. Cuando se recupera el $\mathbf{L}$. E. de la matriz, por conducto de la cánula de KeyesUlltzman, conectada con la jeringa, el resultado es solamente la cantidad de contraste que se encuentra en este momento en las trompas, que es lo único que pasa al peritoneo.

d) L. E.* tiene propiedades bacteriostáticas y probablemente curativas, de focos sépticos tubarios larvados.

e) L. E., es un contraste más transparente que el Lipiodol.

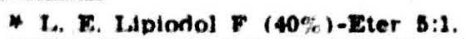

PREPARACION DE LA MEZCLA LIPIODOL-ITER.-La jeringa grande contiene 5 c. c. Lpiodol $r(40 \%)$. Con la jeringa chica inyectamos en la jeringa grande 1 c. c. de eter sulfúrico

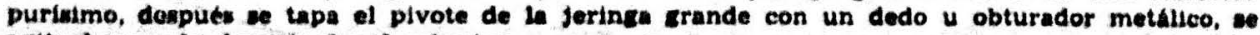
bitit in mexela durante 3 a minutos. 
3.-La mezcla L. E., no es irritante ni produce inflamación de los genitales internos, ni peritoneo.

4.-No es tóxico.

5.-Con 5 a 6 c. c. de la mezcla L. E., obtenemos las placas necesarias, para el estudio de la matriz y de las trompas y después de terminar la última placa, todavía aspiramos en la jeringa, gran parte de la mencionada cantidad.

6.-Por la tensión del éter, la impregnación de las mucosas con la sustancia del contraste, es íntima, obteniendo imágenes claras y detalladas.

7.-La mezela de L. E., se absorbe de la pelvis entre 3 y 8 semanas, siendo la velocidad de absorción, un factor individual.

8.-La absorción de la mezcla de L. E., dentro de la trompa cerrada, es, aproximadamente, entre 2 y 3 meses.

9.-L. E., es la combinación más inocua, en el sistema vascular del conejo. Las dosis mínimas mortales intravenosas, en el conejo de peso promedio de 1.200 a 1.400 gramos, son: L. E., entre $21 / 2$ a $23 / 4$ c. c.; Lipiodol F., entre 1 a $11 / 4$ c. c. 